
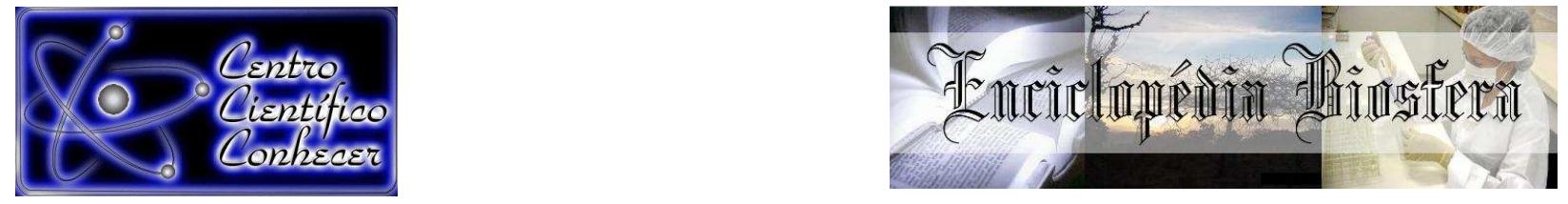

\title{
ANÁLISE ESPACIAL E IDENTIFICAÇÃO DE ALTERAÇÕES NO ZONEAMENTO URBANO DA CIDADE DE ALTAMIRA - PA
}

\author{
Alan Nunes Araújo', Paloma Ioná dos Santos Mesquita², Enoque Gomes de Morais ${ }^{3}$ \\ ${ }^{1}$ Professor Mestre da Faculdade de Engenharia Florestal da Universidade Federal \\ do Pará (alannunesaraujo@gmail.com) Altamira-Brasil \\ ${ }^{2}$ Engenheira Agrônoma na Proterra Engenharia, Brasil \\ ${ }^{3}$ Professor Especialista da Faculdade de Geografia da Universidade Federal do \\ Pará, Brasil
}
Recebido em: 08/09/2015 - Aprovado em: 14/11/2015 - Publicado em: 01/12/2015 DOI: http://dx.doi.org/10.18677/Enciclopedia_Biosfera_2015_077

\begin{abstract}
RESUMO
Considerar o Planejamento urbano nos leva a vários mecanismos de garantia da função da cidade, dentre estes se destacam a hierarquização urbana e seu posterior zoneamento, que se evidencia através das zonas de uso e ocupação do solo, a fim de garantir a organização, o entendimento do espaço e a análise do desempenho de cada área, possibilitando também compreender as necessidades específicas de cada localidade. O zoneamento é apenas um dos requisitos integrantes do plano Diretor, que é o documento fundamental para ordenar o desenvolvimento das cidades. Este é regulamentado pelo estatuto das cidades, responsável por garantir o bem estar social e o zelo da propriedade urbana. A cidade de Altamira-PA, conta com o Plano Diretor Municipal vigente aprovado no ano de 2011 e elaborado com base nos dados de 2010, sendo neste ano justamente o período que marca uma intensa transformação na cidade, acelerada pelo processo de atração migratória e infraestrutura urbana, por ser cidade alvo de um empreendimento de grandes proporções como é o caso da Usina Hidroelétrica de Belo Monte. O presente estudo teve como finalidade explicitar o processo de urbanização ocorrido na cidade de Altamira (Pará) nos últimos anos incentivados pela construção da Usina Hidroelétrica de Belo Monte e sua consequência na reorganização espacial atual, utilizando a geotecnologia como poderosa ferramenta na identificação e análise espaço-temporal das alterações no zoneamento urbano municipal a partir de uma análise intra-urbana da cidade.
\end{abstract}

PALAVRAS-CHAVE: Estrutura Intra-Urbana, Hierarquia urbana, Plano Diretor Municipal, Zoneamento 


\title{
URBAN CITY OF ALTAMIRA-PA
}

\begin{abstract}
To consider the urban Planning in the group to several mechanisms of warranty of the function of the city, among these they stand out the urban hierarchization and his subsequent zoning, that it is evidenced through the use areas and occupation of the soil, in order to guarantee the organization, the understanding of the space and the analysis of the acting of each area, also making possible to understand the specific needs of each place. The zoning is just one of the integral requirements of the Master plan, that is the fundamental document to order the development of the cities. This is regulated by the statute of the cities, responsible for guaranteeing the good to be social and the devotion of the urban property. The city of Altamira-shovel, counts with the effective Municipal Master plan approved in the year of 2011 and elaborated with base in the data of 2010, being on this year exactly the period that marks an intense transformation in the city, accelerated for the process of migratory attraction and urban infrastructure, for being city white of an enterprise of great proportions as it is the case of Beautiful Monte's Hydroelectric Plant.The present study had as purpose explicit the urbanization process happened in the city of Altamira (Pará) in the last motivated years for the construction of Beautiful Monte's Hydroelectric Plant and his/her consequence in the current space reorganization, using the geotechnology as powerful tool in the identification and space-temporary analysis of the alterations in the municipal urban zoning starting from an intra-urban analysis of the city.
\end{abstract}

KEYWORDS: Municipal Master plan; Urban hierarchy; Zoning; Structures Intraurban.

\section{INTRODUÇÃO}

A adoção de técnicas inerentes ao planejamento urbano são atores fundamentais para estabelecer a organização e ordenação territorial, facilitando a compreensão dos fenômenos espaciais e a orientação de ações futuras através de uma melhor utilização dos recursos existentes. Pode-se entender planejamento urbano como o processo que envolve a coleta, organização e análise sistematizada das informações para se chegar a decisões ou escolhas acerca das melhores alternativas para aproveitamento dos recursos disponíveis, com a finalidade de se atingir metas específicas no futuro e que levem a melhoria de determinada situação e ao desenvolvimento das sociedades humanas (SANTOS, 2000).

No planejamento urbano, é importante analisar o espaço de forma sistêmica, no qual as características físicas são comumente analisadas em conjunto com as características econômicas, sociais, populacionais e administrativas, fomentando uma análise geral e específica de cada localidade e identificando suas respectivas funções. A esse respeito, LEITE \& BRITO (2011) salientam que as identificações das funções de cada área são essenciais para apresentar planos e propostas de desenvolvimento urbano que visem melhorias no bem-estar e na qualidade de vida nas cidades.

A definição funcional dos espaços urbanos, e sua posterior ordenação, passa a ser um modelo de classificação, em que cada tipo e forma de apropriação da área são levados em consideração e agrupados, gerando uma classificação de uso e ocupação do solo. Um exemplo de ações advindas do mapeamento do uso da terra são os zoneamentos, que podem ser destinados a diversas finalidades, como 0 
zoneamento ambiental, o zoneamento agroflorestal e o zoneamento urbano (LEITE \& BRITO, 2011).

Sobre esse assunto, SANTOS (2004) esclarece que:

Zonear é a compartimentação de uma região em porções territoriais, obtida pela avaliação dos atributos mais relevantes e de suas dinâmicas. Cada compartimento é apresentado como uma "área homogênea", ou seja, uma zona (ou unidade de zoneamento) delimitada no espaço, com estrutura e funcionamento uniforme (p.69).

Já o zoneamento urbano, objeto de estudo neste trabalho, agrupa localidades de características semelhantes e as diferencia sob a mesma ótica, a fim de estabelecer melhor planejamento de acordo com as diferentes especificidades das áreas.Sobre este assunto, BRASIL (2014) define Zoneamento Urbano como sendo um instrumento utilizado nos planos diretores, e através do qual a cidade é dividida em áreas sobre as quais incidem diretrizes diferenciadas para o uso e a ocupação do solo.

Essa classificação do uso e ocupação do solo tem como principal objetivo a busca por um planejamento urbano eficiente, sendo que uma importante ferramenta para o sucesso deste planejamento é o Plano Diretor de cada cidade, instrumento inicial de ordenação da expansão urbana de cada município, garantido por lei federal, para a gestão da urbanização nas cidades. Segundo BRASIL (2001, p.40) "o Plano Diretor pode ser definido como um conjunto de princípios e regras orientadoras da ação dos agentes que constroem e utilizam o espaço urbano".

Segundo a Lei Federal 10.257/2001 (BRASIL, 2002) o plano diretor é obrigatório para municípios com mais de 20 mil habitantes; Integrantes de Regiões Metropolitanas; áreas de interesse turístico e/ou situados em áreas de influência de empreendimentos ou atividades com significativo impacto ambiental na região ou país.

Quanto à importância e função do plano diretor, CARVALHO \& BRAGA (2001) classificam-no como um instrumento básico da política municipal de desenvolvimento e expansão urbana, que busca ordenar o pleno desenvolvimento das funções sociais da cidade e garantir bem-estar dos habitantes. Ainda conforme CARVALHO \& BRAGA (2001), o plano diretor é a ordenação do uso e ocupação do solo urbano, processo mais conhecido como Zoneamento urbano. Este zoneamento em sua forma mais simplificada agrupará os espaços urbanos de acordo com suas respectivas funções (residenciais, industriais e comerciais).

Corroborando com essa ideia PEREIRA JÚNIOR et al. (2015) asseguram que:

\footnotetext{
Planejar o desenvolvimento da cidade é uma maneira de evitar e corrigir as distorções do crescimento urbano e seus impactos sobre o meio ambiente, pois a ordenação e o controle do uso do solo disciplinam a instalação e o desenvolvimento dos empreendimentos e atividades no espaço urbano, com finalidade de atenuar 0 avanço da poluição e de outros danos ambientais (p. 2640).
}

Segundo CHENG (2003) o uso do solo pode ser definido quanto ao grau de aglomeração de atividades com fortes relações de dinâmica entre elas, assim o uso pode ser definido de acordo com a atividade econômica e funcional à que se 
destina. O mapeamento do uso e ocupação do solo e sua correlação com outros indicadores econômicos, sociais, populacionais e ambientais contribui de forma significativa no zoneamento do espaço urbano e sua evolução espaço-temporal, sempre em consonância com o Plano Diretor vigente.

Para FARINA (2006), a alteração no território também é uma problemática gerada pela expansão urbana, que modifica a organização do espaço, assim como as relações do homem com o ambiente. Neste sentido POLIDORO \& BARROS (2012) afirmam que:

\begin{abstract}
A cidade brasileira emerge como espaço de contradições, de um lado a parcela da população que se insere na nova divisão territorial do trabalho e de outro a camada excluída, que se utiliza do improviso para a sobrevivência, expondo distintos processos paradoxais de expansão urbana; um pautado na ilegalidade e outro na legalidade, porém ambos maculados pela exclusão (p. 325).
\end{abstract}

O presente estudo tem como finalidade explicitar o processo de urbanização ocorrido na cidade de Altamira-Pará nos últimos anos incentivados pela construção da Usina Hidrelétrica de Belo Monte e suas consequências na organização espacial atual, utilizando a geotecnologia como ferramenta na identificação e análise espaçotemporal das alterações no zoneamento urbano municipal a partir de uma análise intra-urbana da cidade.

\title{
REVISÃO DE LITERATURA
}

\section{Estatuto das Cidades}

Referente a regulamentação e planejamento urbano das cidades, a lei federal 10.257 de 10 de julho de 2001, mais conhecida como Estatuto das Cidades, estabelece, em Parágrafo único, normas de ordem pública e interesse social que regulam o uso da propriedade urbana em prol do bem coletivo, da segurança e do bem-estar dos cidadãos, bem como equilíbrio ambiental (BRASIL, 2002).

Por outro lado, os autores CARVALHO \& ROSSBACH (2010) afirmam também que o estatuto das cidades não trata apenas da terra urbana, a lei não só estabelece diretrizes e preceitos sobre planos e planejamento urbano, mas também regulação estatal, fiscal e jurídica sobre as propriedades fundiárias e imobiliárias. Portanto, o acesso à terra, seja ela urbana ou rural, sempre foi um dos temas mais importantes da história da humanidade. Os mesmos autores defendem ainda que "o acesso à terra nas sociedades pobres que se urbanizam é mais crucial. E essa é a questão chave do estatuto das cidades".

A Lei 10.257/2001 possui uma série de instrumentos, e busca promover a regulação do desenvolvimento urbano, estes encontram-se descritos no Art 4ํㅜ da Lei que dispõe os seguintes instrumentos de planejamento municipal:

III - planejamento municipal, em especial:a) plano diretor; b) disciplina do parcelamento, do uso e da ocupação do solo; c) zoneamento ambiental; d) plano plurianual; e) diretrizes orçamentárias e orçamento anual; f) gestão orçamentária participativa; g) planos, programas e projetos setoriais; h) planos de desenvolvimento econômico e social (BRASIL, 2002). 
A importância da Lei das cidades é inegável em seus objetivos específicos estabelecidos por lei. Este é o Norte para a gestão política, social e ambiental que são intrínsecas no sistema urbano de cada município. Este também, em alguns casos, é considerado um aliado da urbanização ambientalmente correta, pois as leis estimulam que as prefeituras adotem a sustentabilidade ambiental em seus planos diretores, assim como preveem normas para garantir a realização de Estudos de Impacto Ambiental para grandes obras que sejam implementadas.

Porém, apesar de se estabelecer instrumentos para garantir uma urbanização socioambiental justa, estes instrumentos resvalam em sua inaplicabilidade, isto é, muitos objetivos esbarram na conjuntura política estabelecida no próprio país. Segundo CARVALHO \& ROSSBACH (2010) os países tidos como capitalistas periféricos, não conseguem aplicar em suas cidades as leis urbanísticas assim como os países do mundo desenvolvido podem aplicar em suas cidades, pois nestas cidades o Estado detém realmente o controle sobre a totalidade do solo urbano seguindo assim as leis exigidas.

Portanto, a partir do entendimento da ideia defendidas por estes autores, observou-se que ao se analisar países periféricos, o Estado não detém total controle sobre o solo urbano, as maiores áreas ficam concentradas nos centros, envolvidas em um grande mercado de especulação imobiliária que só é acessível à uns poucos. As áreas que ficam à disposição da população sem o poder aquisitivo exigido para se pertencer as áreas centrais, regularizadas e no padrão urbanístico garantindo em lei, acabam concentradas nas áreas periféricas, consideradas ambientalmente frágeis, sendo em margens de cursos d'água, encostas deslizantes, várzeas inundáveis, dentre outras alternativas restantes.

Segundo CARVALHO \& ROSSBACH (2010, p. 09) "As principais formas de moradias precárias são produtos de loteamentos piratas e clandestinos ou de invasão de terras, que dão início a formação de favelas". Esses fatores são apenas um dos exemplos que reforçam a inoperância em muitos casos da lei das cidades em seus objetivos socioambientais.

\section{Plano Diretor e Uso e Cobertura do Solo de Altamira - PA}

O uso do solo é o rebatimento da reprodução social no plano do espaço urbano e a ocupação do solo, por sua vez, é a maneira pela qual a edificação pode ocupar o terreno urbano, em função dos índices urbanísticos incidentes sobre o mesmo. Logo, compreende-se a finalidade regulatória deste procedimento e sua necessidade fiscalizadora para validação em um município (TAKEDA et al., 2013).

Segundo Vaz (1996, p.01) "o objetivo da prefeitura ao elaborar leis de uso e ocupação do solo deve ser democratizar o acesso à terra e a qualidade de vida". Segundo o mesmo autor, a legislação de uso e ocupação do solo é de suma importância, pois além de normatizar as construções para que sejam erigidas em seus devidos lugares, esta possui influência da estrutura intra-urbana da cidade e também em sua economia (VAZ, 1996).

Para MEDINA (2013, p.541) as leis de uso e ocupação são em essência uma estratégia de desenho, pois "é um sistema de implementação da forma préelaborada, dentro da estrutura política do Estado Moderno, também pré-acordada, a partir da regulamentação das práticas dos agentes sociais produtores do espaço urbano". 
Tradicionalmente, a legislação de uso e ocupação do solo concentra-se em normas técnicas de edificações e no zoneamento da cidade (VAZ, 1996). Sendo assim, é estabelecido o que pode ou não ser construído e o tamanho das construções nos terrenos dos municípios, definidos a partir da relação entre o tamanho do terreno e a quantidade de pessoas, assim como pelas atividades desenvolvidas, sendo: comércio, moradias, serviços, indústrias, etc., bem como pelo tipo dos prédios e tamanho dos lotes, dentre outros (TAKEDA et al., 2013).

Como já especificado, o plano diretor é um dos instrumentos estabelecidos no Estatuto das cidades, porém este é implementado como uma responsabilidade do poder público municipal, pois cabe ao plano diretor a premissa constitucional de garantir o desempenho da função social da cidade e das propriedades urbanas.

De acordo com BRASIL (2002) é precisamente o plano diretor, como instrumento legal, que define em níveis municipais, os limites, as capacidades e as obrigações envolvendo a propriedade urbana. Segundo o Estatuto, o objetivo do Plano diretor não é apenas resolver todos os problemas da cidade, mas também ser um instrumento para a definição de estratégias para a intervenção imediata, estabelecendo também princípios de ação em conjunto.

O atual plano diretor de Altamira teve sua última revisão em dezembro de 2010 e foi aprovado segundo a Lei o 2.178 de 07/04/2011, e estabelecidos com uma série de objetivos descritos no Art. 10, que são eles:

I- Assegurar o desenvolvimento Econômico, social e físico do Município e preservação do meio ambiente ecologicamente equilibrado...;

II- Fortalecer a posição do Município na região;

III-Adequar e promover a compatibilização do processo de planejamento ambiental e a articulação do território do município aos planos e projetos nacionais;

IV- Instituir as formas de parcerias entre o poder público e a iniciativa privada na elaboração e execução dos projetos de interesse público que dinamizem o setor produtivo;

V- Instituir os incentivos que estimulem o ordenamento do uso e ocupação do solo (ALTAMIRA, 2011).

Ficou estabelecido o ordenamento do território em macrozonas subdivididas em: Macrozonas Urbanas, Macrozonas de Interesse Ambiental, Macrozonas Indígenas e Macrozona Rural. Dentre a Macrozona Urbana, têm-se estabelecido o perímetro urbano de Altamira como Macrozona Urbana I; a sede do distrito de Castelo dos Sonhos como Macrozona II; e a sede do distrito de Cachoeira da Serra, como Macrozona III.

As diretrizes do plano diretor subdividem também as Macrozonas Urbanas conforme zonas de uso e ocupação. O Município de Altamira, estabelecido pelo Plano Diretor como Macrozona Urbana I, tem suas subdivisões caracterizadas da seguinte forma:

I) Zona da Orla: Incrementada por atividades turísticas e paisagísticas, sendo permitido o uso habitacional residencial e comercial;II)Zona Central Histórica: Área de incentivo ao patrimônio cultural;III) Zona Central: Áreas caracterizadas pela ocupação de habitações residenciais, onde se pretende incentivar a verticalização, assim como uso comercial de grande porte;IV) Zona Mista 1: Uso residencial e comercial de pequeno porte, com máximo de três pavimentos;V) Zona Mista 2: Uso residencial e comercial de pequeno porte, com máximo de três pavimentos; $\mathrm{VI}$ ) Zona Habitacional 1: Configurada por áreas habitacionais residenciais mais próximas ao 
centro;VII) Zona Habitacional 2: Área habitacional residencial onde se pretende incentivar os condomínios, chácaras e etc.;VIII) Zona de Interesse Paisagístico: Áreas públicas ou privadas com atributos naturais importantes;IX) Zona de Industria e Abastecimento 1: Áreas industriais de atividades de produção e transformação tidas como perigosas; $X$ ) Zona de Indústria e Abastecimento 2: Áreas industriais de atividades de produção e transformação tidas como não perigosas; XI) Zona de Equipamentos Estruturantes: Áreas de interesse Institucional ou Zonas estratégicas, públicas ou particulares.

\section{MATERIAL E METODOS}

\section{Caracterização da Área Alvo}

O município de Altamira-PA, situa-se no sudoeste do Estado do Pará, localizando-se na Latitude 0392'02 21,80" S e Long itude 52'10'51 06,03"W, situando-se às margens do Rio Xingu, um dos principais afluentes do rio Amazonas, e cortado pela BR-230 -Rodovia Transamazônica, (Figura 01) sendo distante da capital Belém cerca de $920 \mathrm{Km}$ via rodovia (MOURA \& RIBEIRO, 2009).

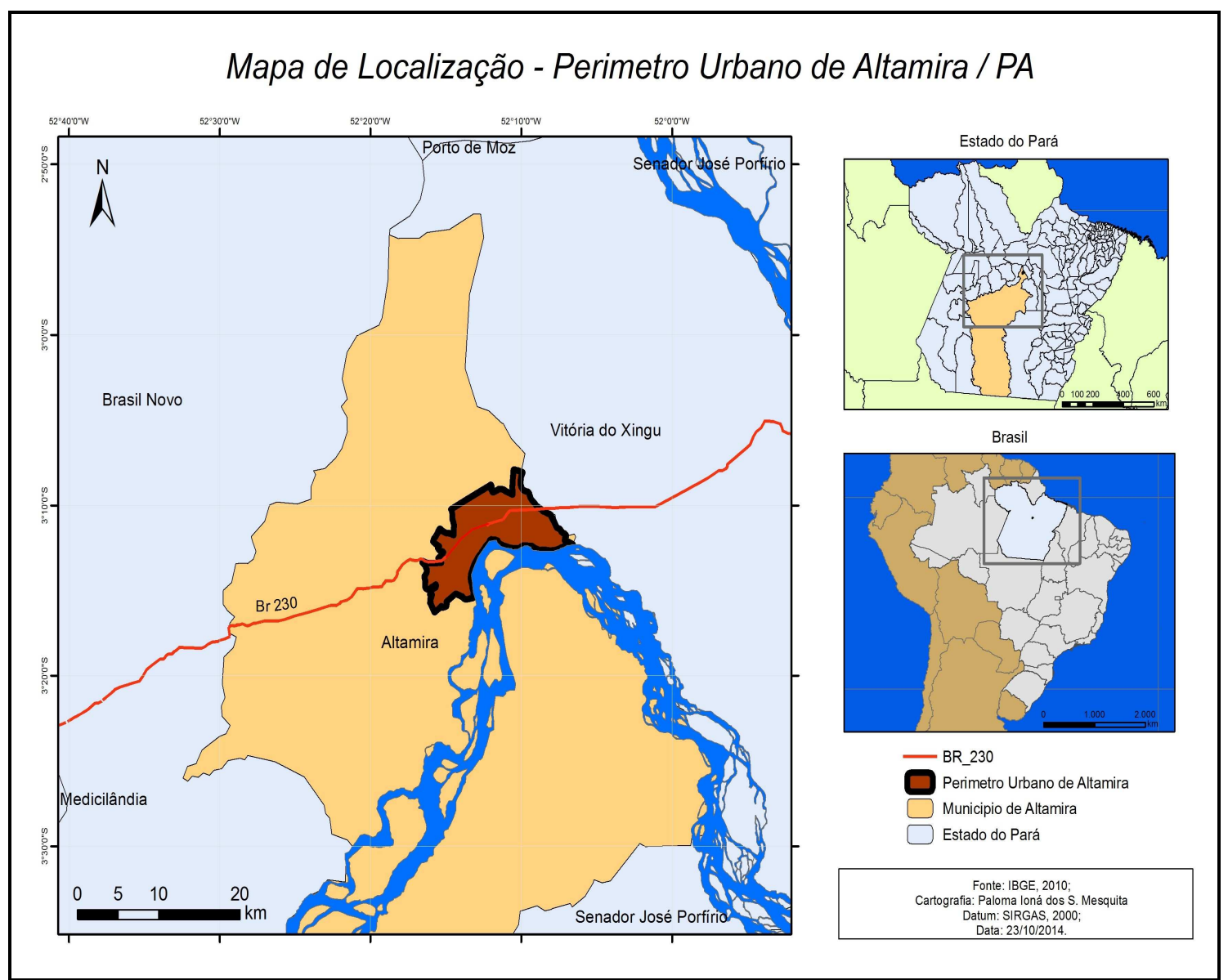

FIGURA 1: Localização da Área de Estudo. Fonte: IBGE. Elaboração: Mesquita (2014)

Este município encontra-se em processo de intensa expansão urbana, iniciado e impulsionado pelo início e execução das obras da Usina Hidrelétrica de Belo Monte. Grandes investimentos como este afetam o dinamismo econômico e consequentemente a expansão da população, pois o processo de mobilidade populacional é estimulado pelo fortalecimento econômico e oferta de empregos que 
atraem migrantes de outras regiões (FERNANDES et al., 2009).

Logo, pode-se salientar que o dinamismo alavancado pela implantação de obras de investimento, sejam elas públicas ou privadas, afetam o processo migratório nas regiões foco. Altamira caracteriza-se regionalmente como localidade central tornando-se elemento integrador entre os demais municípios abrangidos pela construção da Usina, sofrendo também com impactos ambientais, populacionais, econômicos e sociais, principalmente a partir de 2011, ano em que foram iniciadas as referidas obras.

Conforme o Censo de 2010, a população total de Altamira, se constituía em 99.075 habitantes. Apesar de não haver dados Censitários mais recentes para comparação, os dados estimativos do IBGE quanto a população para este ano de 2014 são de 106.786 habitantes, sem contar as migrações pendulares dos municípios circunvizinhos, onde estas caracterizam-se por ser uma migração com tempo definitivo, que ocorre devido à necessidade de deslocamento que pessoas realizam para trabalhar e estudar (NOGUEIRA \& RIPPEL, 2012).

Altamira conta com uma unidade territorial de $161.445,90 \mathrm{~km}^{2}$ e uma população registrada no censo de 2010 , de 99.075 , porém as estimativas neste ano 2014 são de 106.768, conforme dados do IBGE (2014). Hoje é uma área de influência de empreendimentos de interesse nacional, por ser cidade sede da construção da Usina Hidrelétrica de Belo Monte, instalada na região desde 2009, com pico no processo de construção a partir de 2011.

\section{Levantamento dos Dados e Tratamento da Informação Geográfica}

Como ferramenta para atingir os objetivos propostos no trabalho, afim de identificar as alterações no Zoneamento da cidade de Altamira-PA, a partir de uma análise espacial com o uso de geotecnologias aplicadas, elaborou-se uma base cartográfica a partir de softwares de SIG (Sistemas de Informação cartográficas) para estabelecer Vetores que serviram de bases para os mapas elaborados e sua posterior discussão.

Bases cartográficas digitais de Setores Censitários IBGE 2010; Plano Diretor Municipal Elaborado pela Prefeitura Municipal de Altamira com base na Lei №2.178 de 07 de Abril de 2011; Novo Perímetro urbano com base na Lei №3.091, de 17 de Setembro de 2012; Imagem RAPIDEYE (2011), Resolução Espacial de 5 metros;Arruamento Atualizado Altamira-PA; Análise do Modelo MorfológicoFuncional proposto por Amorim Filho (2005); Mapa de Zoneamento do Perímetro Urbano de Altamira (Plano Diretor Municipal).

Os procedimentos metodológicos para estabelecer a ordenação das etapas de elaboração do trabalho, e execução, foram realizados no período de agosto de 2014 a março de 2015, e dispostos da seguinte forma:

Formação do Referencial Teórico; Análise da Paisagem Urbana; Levantamento em campo com auxílio de GPS de Navegação para rastreio de trajetórias entre as vias e marcação de pontos identificados como foco de alteração das vertentes estabelecidas no Zoneamento; Registro Fotográfico; Análise de Dados; Elaboração de Mapas de Representação de Dados; Elaboração de Mapa para Hierarquização intra-urbana conforme definido por AMORIM FILHO (2005); Atualização do Mapa de Zoneamento do Perímetro Urbano de Altamira com base em informações atuais; Elaboração do Relatório Final e Socialização dos Resultados. 
O modelo morfológico-funcional é um modelo de zoneamento proposto por AMORIM FILHO em 2005, onde este propõe um exemplo de organização do espaço urbano a partir de suas funções e características hierárquicas. A partir de seu estudo, tem-se a seguinte classificação, de acordo com as funções especificadas no Quadro 01.

QUADRO 1: Níveis de Hierarquia urbana

\begin{tabular}{|c|c|c|c|}
\hline \multicolumn{4}{|c|}{ Níveis da Hierarquia Urbana } \\
\hline Zona Central & Zona Pericentral & Zona Perifér & ana \\
\hline $\begin{array}{l}\text { Centro principal extenso, } \\
\text { com um processo de } \\
\text { diferenciação funcional } \\
\text { interna (poli centralidade } \\
\text { interna); equipamentos } \\
\text { terciários raros e } \\
\text { sofisticados, } \\
\text { polarização regional e até } \\
\text { mesmo macrorregional; } \\
\text { Morfologia e paisagem } \\
\text { marcadas pela forte } \\
\text { densidade de construções } \\
\text { predominantes em altura; } \\
\text { forte movimento de } \\
\text { veículos e de pessoas; } \\
\text { problemas de } \\
\text { congestionamento, de de } \\
\text { ambientais e função } \\
\text { segurança; residencial presente, mas } \\
\text { resuperada pelas terciárias. }\end{array}$ & $\begin{array}{l}\text { Bastante extensa } \\
\text { espacialmente; } \\
\text { formada por bairros, } \\
\text { que se diferem } \\
\text { socioeconomicamente, } \\
\text { embora as classes } \\
\text { médias predominem; } \\
\text { Predominância da } \\
\text { função residencial; } \\
\text { presença re } \\
\text { subcentros local er } \\
\text { alcance lom } \\
\text { regional, } \\
\text { principalmente } \\
\text { aqueles formados por } \\
\text { grandes equipamentos } \\
\text { de } \\
\text { (Complexos serviços } \\
\text { hospitalares, } \\
\text { Universitários, } \\
\text { Turísticos e de Lazer) } \\
\text { ou de comércio } \\
\text { (Shoppings Centers). }\end{array}$ & 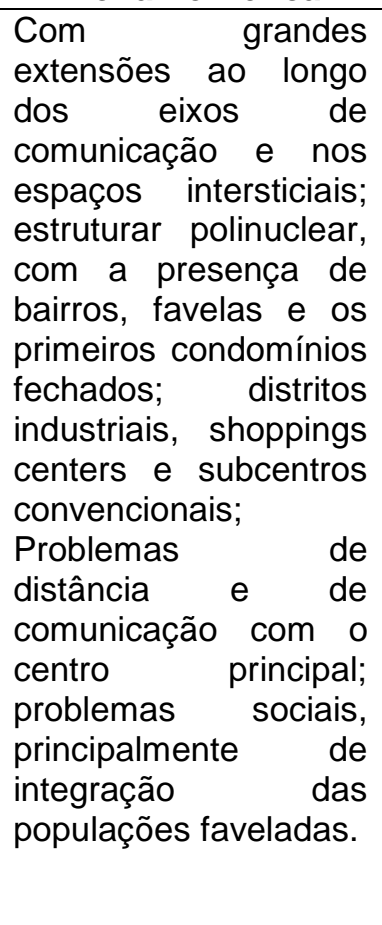 & 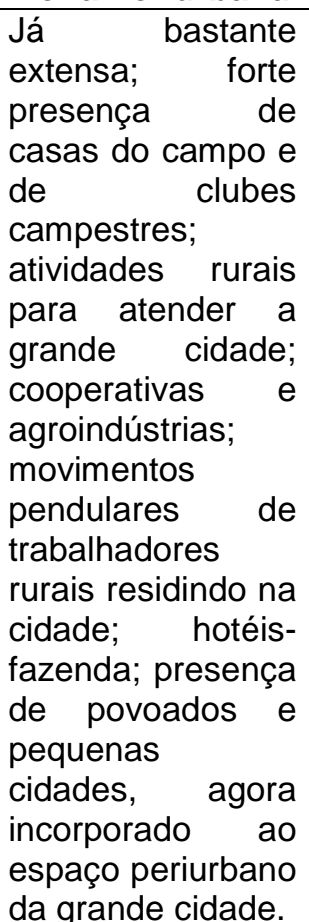 \\
\hline
\end{tabular}

Fonte: Adaptado de Amorim Filho (2005)

\section{RESULTADOS E DISCUSSÃO}

\section{Densidade Demográfica e Moradores por Domicilio Ocupado}

A fim de compreender o processo de expansão demográfica e a modificação do espaço urbano, foi imprescindível a análise de dados demográficos da cidade, com base no Censo de 2010 do IBGE, sobre os setores censitários do Município. A Figura 2 cruza dados de Habitantes por $\mathrm{km}^{2}$ do último censo sobre os setores censitários e ajuda a perceber a distribuição demográfica na cidade neste período pré-expansão. É possível notar a densidade concentrada nos principais núcleos centrais representados pelas hachuras mais escuras. 


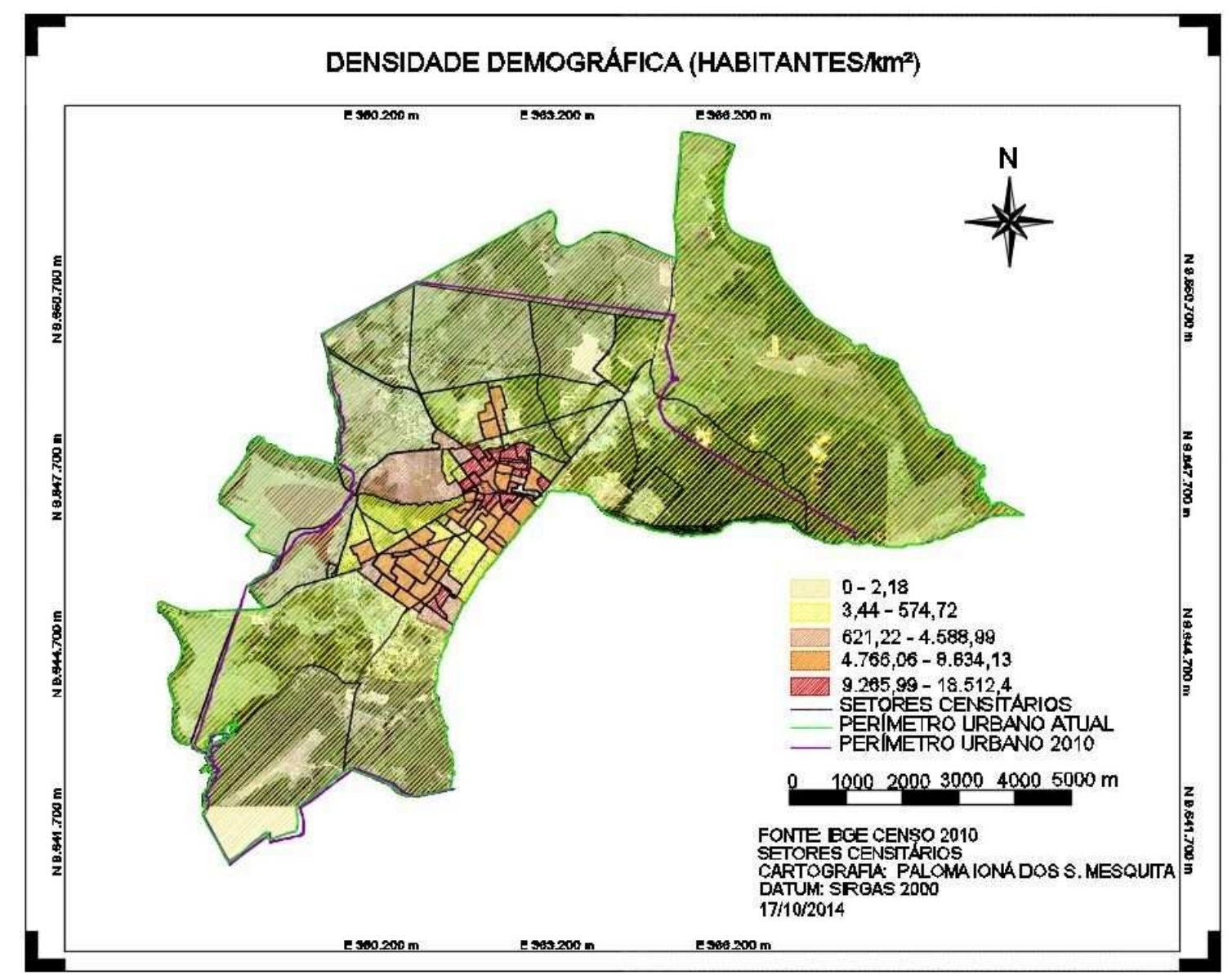

FIGURA 2: Densidade Demográfica (habitantes/km²). Fonte: IBGE. Elaboração: Mesquita (2014).

Os setores são as menores unidades territoriais e são sempre pertencentes à uma área de ponderação, a mesma corresponde ao nível geográfico definido para a aplicação de procedimentos estatísticos que permitem que os dados de amostragem sejam válidos. Alguns dados não são considerados confiáveis ou significantes quando dispostos em uma grande escala, porém quando analisados em recortes mínimos de áreas, estes tornam-se válidos.

A Região central apresenta-se como área já consolidada e intensamente ocupada por comercio e serviços, que devido ao sobrepujamento destas formas de ocupação, encontra-se limitada para a residência unifamiliar. Entretanto, já é possível perceber que áreas secundárias, mas ainda próximas ao grande centro, também já concentravam uma quantidade populacional expressiva nesta época.

As áreas mais afastadas destes centros e dos principais eixos viários apresentavam ainda baixa densidade demográfica no ano de 2010, ficando à disposição da população sem poder aquisitivo exigido para residir nas áreas centrais. Estas localidades são áreas que margeiam o perímetro urbano de 2010, 0 que as configurava como áreas de expansão urbana.

Segundo COSTA (2013) "O surgimento de grande quantidade de novas áreas e novas ocupações nas áreas periféricas mais distantes do centro provocam expansão territorial com baixos níveis de densidade demográfica, o que pode indicar tendência à dispersão".

Apesar da baixa densidade pode-se perceber na Figura 3, que estas áreas mais afastadas apresentam níveis equivalentes de ocupação por domicílio que as áreas mais próximas ao centro ou o próprio centro. 


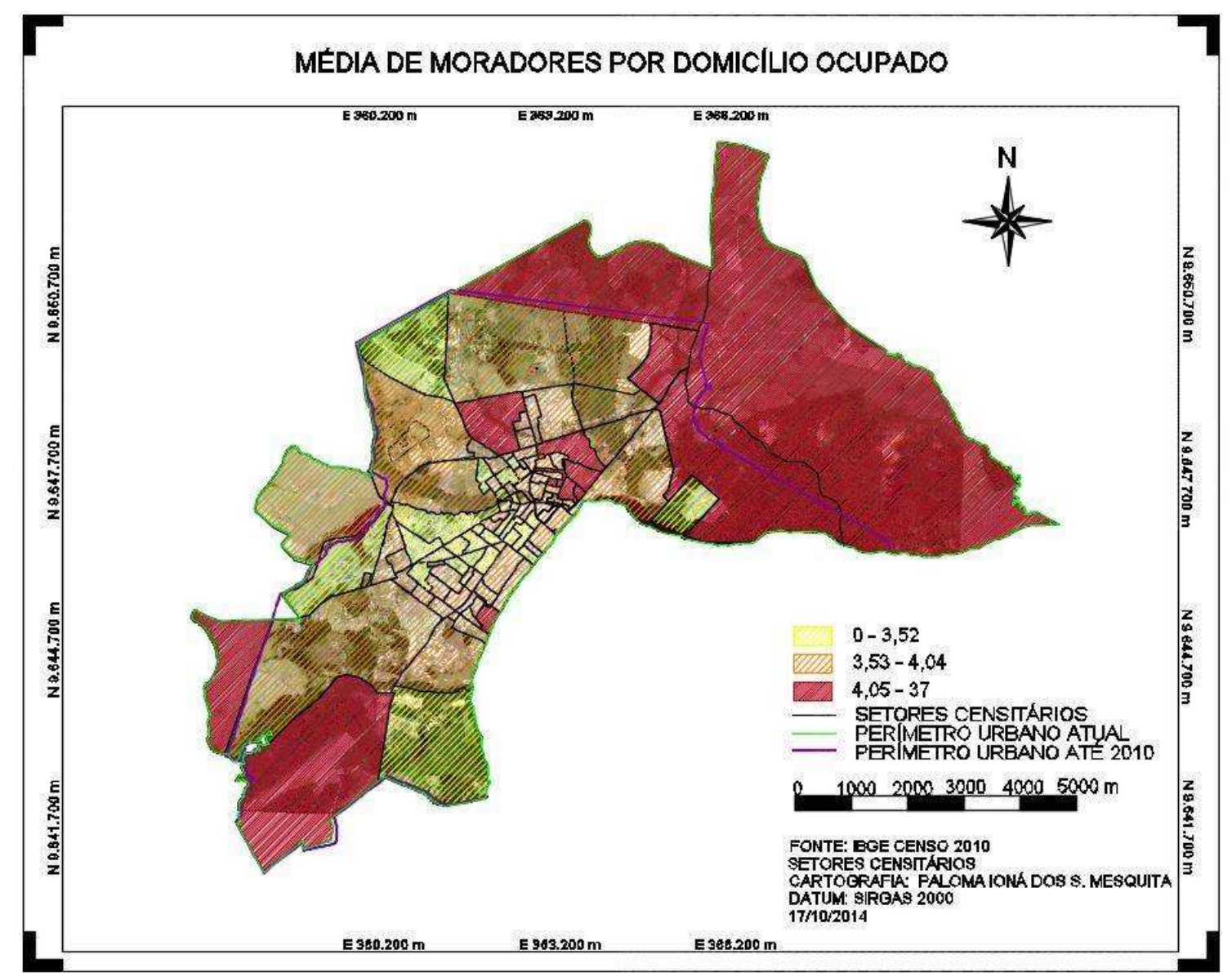

FIGURA 3: Média de Moradores por Domicílio Ocupado. Fonte: IBGE. Elaboração: Mesquita (2014).

Essas características quando relacionadas a situação de Altamira no ano de 2010, e levando em consideração também o perímetro urbano na época vigente, percebe-se que estas eram áreas recém abarcadas pelo perímetro urbano, que antes se constituíam como rurais, com forte presença de chácaras e fazendas e que então passam a ser chacreamentos urbanos, que mais tarde evoluíram com o avanço demográfico, para áreas de ocupação mais intensa.Em média, as residências são formadas por famílias mais extensas, muitas vezes fogem do padrão nuclear, formado por pais e filhos, e apresentam mais agregados, e parentes residindo em uma mesma residência.

\section{Ocupação Urbana e Seus Eixos de Ordenação}

A origem da cidade de Altamira ocorreu de forma semelhante ao processo de formação de cidades Amazônicas, isto é, em áreas localizadas as margens de rios e lagoas, no qual a constante utilização da água nas atividades domésticas e agrícolas sempre levaram a população a buscar locais de recursos hídricos fartos e facilmente captados, neste caso a orla do rio Xingu.

O próprio rio servia como eixo hidroviário em um período em que não existiam estradas para escoar pessoas e produtos. Sendo assim, a cidade de Altamira foi ocupada em sentido ascendente a partir de um núcleo central específico. Este centro inicialmente era a região da orla, onde as primeiras habitações foram 
instaladas, assim como os primeiros pontos comerciais.

A partir deste centro a expansão urbana e espacial foi ocorrendo até um novo núcleo ser instaurado na área, denominada hoje como Bairro Centro, envolto pelas Ruas Sete de Setembro, Avenida Djalma Dutra, Comandante Castilho e Pedro Gomes, que formam um bloco de área comercial e serviços, com moradias unifamiliares e alto processo de verticalização dos imóveis somado aos altos valores imobiliários por metro quadrado.

Esta forma de ordenação é bem representada pelo Modelo MorfológicoFuncional de AMORIM FILHO (2005), segundo ARAÚJO et al., (2007), que classificam a cidade em níveis de hierarquia urbana, onde estas se ordenam em quatro zonas, classificadas com base em uma divisão funcional.

A partir classificação hierárquica proposta por AMORIM FILHO (2005), segundo ARAÚJO et al., (2007) é percebível sua representação dentro do cenário urbano da cidade de Altamira-PA representada pelo Mapa de Classificação de Níveis hierárquicos Urbanos, figura 04. É possível observar no mapa as 04 classes hierárquicas subdivididas, como proposto por AMORIM FILHO (2005), onde estas obedecem ao perímetro urbano vigente.

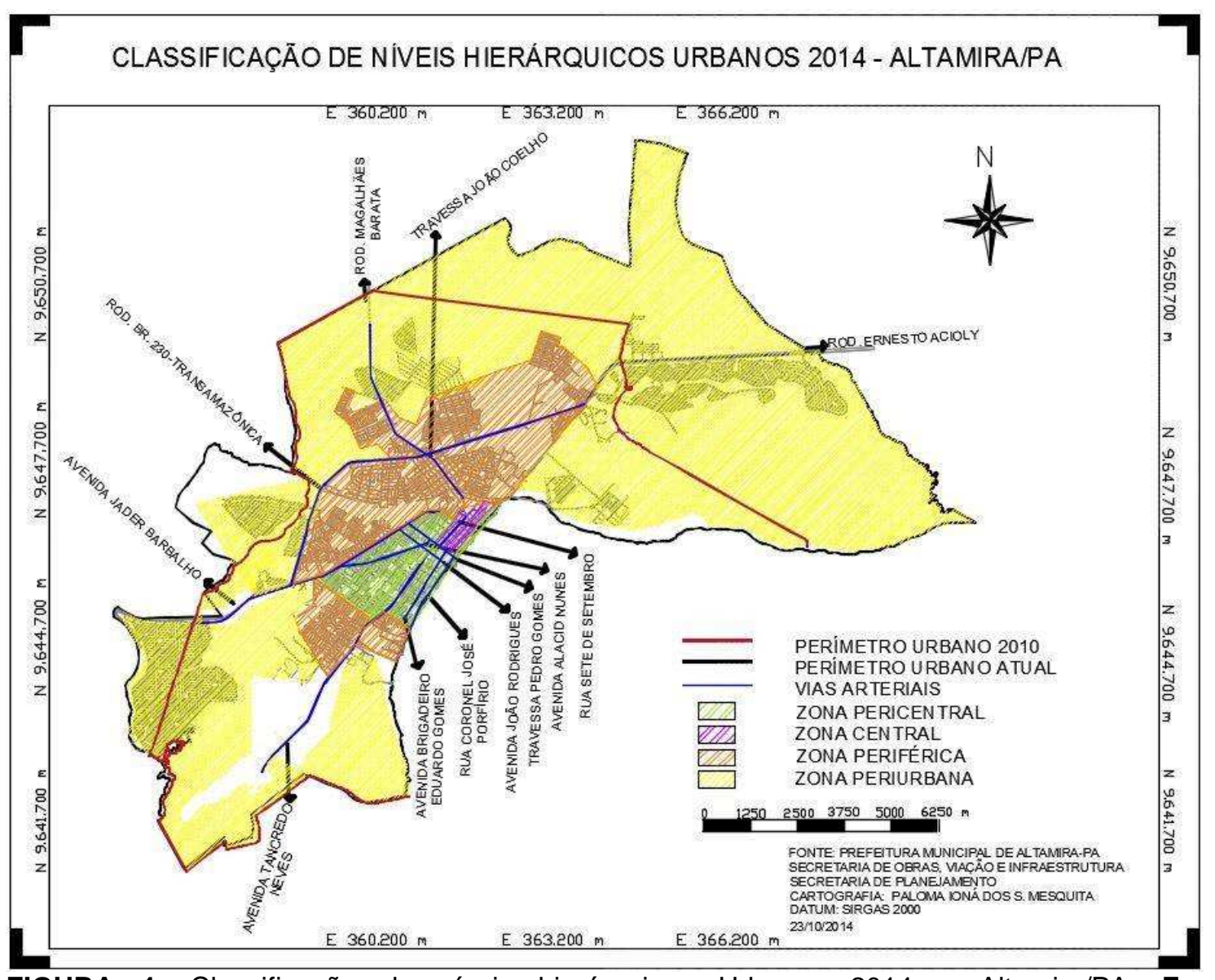

FIGURA 4: Classificação de níveis hierárquicos Urbanos 2014 - Altamira/PA. Fonte: P.M.A./SEOVI/SEPLAN-ATM-PA. Elaboração: Mesquita (2014).

A Zona central, como já mencionado, configura-se como o núcleo central de Altamira e primeira localidade a ser ocupada (Bairro Centro). Tal região é caracterizada por residências multifamiliares com processo intenso de verticalização, contando também com a predominância de equipamentos urbanos terciários 
(principal centro comercial e funcional).

Limítrofes a Zona Central, situam-se as Zonas Pericentrais, dotada de subcentros para oferta de bens e serviços e marcados também por residências habitacionais unifamiliares de alto padrão, esta distribuição pode ser percebida seguindo o curso de vias também principais, como: Avenida Tancredo Neves, Avenida Brigadeiro Eduardo Gomes e Rua Coronel José Porfírio.

A partir da nucleação principal, se estabelecem também as Zonas Periféricas, definidas pelo distanciamento da área central e caracterizados pela predominância de bairros periféricos ocupados por uma população de classes de renda média e baixa, sendo o Bairro Brasília, o principal bairro periférico de acordo com estes padrões e estabelecido a partir de sua via principal, Rua João Coelho. Esta zona periférica conta também com subcentros (centro de comércio, vias arteriais e residências unifamiliares de classe média à baixa (COSTA, 2013).

Ainda nesta Zona, temos os bairros mais distantes da Zona Central situadas a partir dos Bairros Mutirão, Alberto Soares, Bela Vista, que representam os últimos bairros a serem ocupados, recebendo moradias de baixos padrões e famílias das classes menos favorecidas. Esta localidade caracteriza-se também por eixos viários sem pavimentação e situações precárias de habitação, revelando novamente a teorias explicitada por CARVALHO \& ROSSBACH (2010), no qual compreende-se que as áreas centrais, regularizadas com os padrões urbanísticos previstos são ocupadas pela população que pode arcar financeiramente com os custos de morar em uma zona central ou pericentral.

As populações com poder aquisitivo mais baixos são obrigadas a ocupar áreas menos favorecidas à ocupação, isto é, distantes das áreas centrais, com problemas decorrentes de fenômenos ambientais (inundação, ambientalmente frágeis ou urbanisticamente desregulares). Estas características reforçam o modelo de classificação hierárquica adotado por AMORIM FILHO (2005) segundo ARAÚJO et al., (2007), em que foram classificadas as principais características hierárquicas para diferenciação urbana.

\section{Caracterização da Estrutura Intra-Urbana em 2010, Segundo Plano Diretor Municipal}

O Zoneamento do perímetro Urbano da Cidade de Altamira-PA, presente no Plano Diretor Municipal, estabelecido pela Lei N².178 de 07 de Abril de 2011 e vigente até o período atual, foi desenvolvido ainda no ano de 2010 e foi estruturado dentro dos limites do perímetro urbano vigente na época.Este encontra-se desatualizado, com base na Lei $N^{\circ} 3.091$, de 17 de Setembro de 2012, que estabelece um novo perímetro urbano para a cidade.

Como uma das premissas do Plano Diretor, tem-se o objetivo de garantir que a cidade exerça a sua função social e ordenar as propriedades urbanas. O Plano diretor de Altamira, em sua carta de apresentação, menciona que o mesmo foi elaborado a partir de análise da realidade municipal atual, quando da elaboração do plano; caracterização da situação desejada para desenvolvimento municipal; eixos ou linhas estratégicas, assim como diretrizes para o território municipal (ALTAMIRA, 2010).

Conforme pode ser observado na Figura 05, mapa de Zoneamento do Perímetro Urbano estabelecido pelo PDM, este contempla as principais vias consolidadas no município, assim como rota hidroviária, é possível perceber o argumento mencionado anteriormente, em que o desenvolvimento da cidade se ENCICLOPÉDIA BIOSFERA, Centro Científico Conhecer - Goiânia, v.11 n.22; p.151 2015 
estabelece nos sentidos das principais vias arteriais que cortam a cidade.

A zona de expansão urbana, abarcada pelo plano diretor, ressalta os principais vetores de crescimento da cidade, estabelecido em direção das principais Rodovias: Rod. Ernesto Aciolly, Rodovia Magalhães Barata, Rod. Transamazônica e a da Avenida Tancredo Neves.

Quanto aos usos e ocupações estabelecem-se 11 zonas, sendo incialmente 01 Zona Central Histórica, que pode ser percebida na Figura 5, justamente como as áreas já mencionadas anteriormente como núcleo de centralidade do Município, perímetro que margeiam vias principais como Rua Sete de Setembro, Avenida Djalma Dutra e Travessa Pedro Gomes. Esta é caracterizada no Plano como Zona de incentivo à preservação do patrimônio cultural, mantendo unidades habitacionais da categoria uni-habitacional (UH) e a subcategoria de serviços CS1, descrita como serviços profissionais e de negócios empresariais (bancos), de profissionais liberais (escritórios), domiciliares (chaveiros) e consumo local (lanchonetes, barzinhos e mercearias),englobando nesta a Zona Central (ZC), marcada apenas na área situada ao longo da via Sete de Setembro, principal via de comercio da cidade.

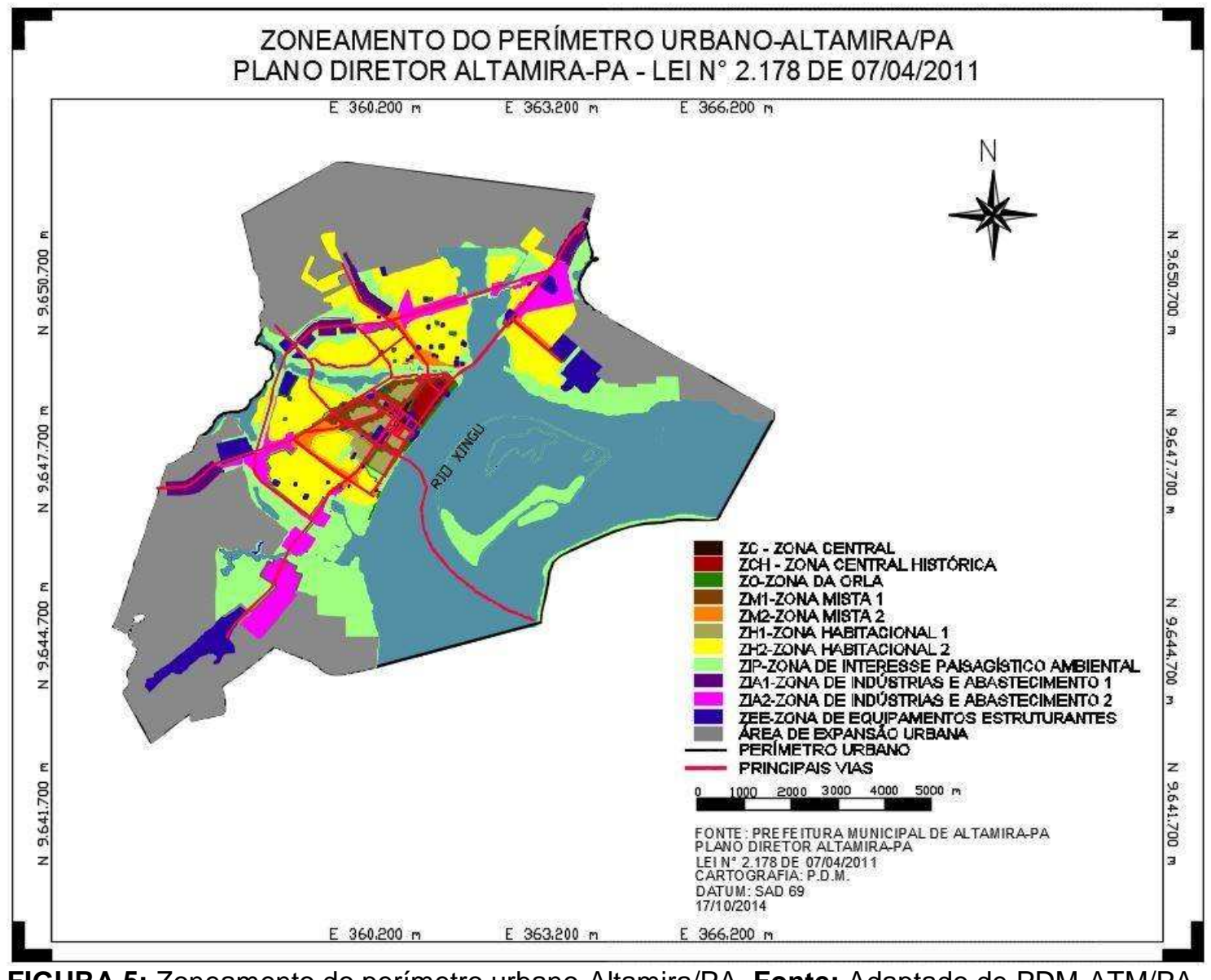

FIGURA 5: Zoneamento do perímetro urbano-Altamira/PA. Fonte: Adaptado de PDM-ATM/PA.

Em relação a esta Zona Central Histórica, situam-se duas Zonas Habitacionais ( $\mathrm{ZH})$, subdividias em Zona Habitacional 1 ( $\mathrm{ZH} 1)$ e Zona habitacional 2 (ZH2), sendo que a primeira é classificada com 1 por sua proximidade ao centro, e descriminada a incentivos de habitações tipo $(\mathrm{PH})$ pluri-habitacionais com tipologias edílicas, onde se incentiva categorias também de uso institucional (Universidades) ou projetos de interesse público, por serem consideradas áreas estratégicas. 
Percebidas facilmente como as Zonas Pericentrais, estabelecidas na classificação hierárquica de AMORIM FILHO (2005) segundo ARAÚJO et al., (2007), em que as ZH2 configurar-se-iam sob esta ótica justamente como periféricas. Conforme a classificação estabelecida o PDM, estas zonas se classificaram desta forma, por serem áreas onde pretende-se incentivar o uso habitacional da subcategoria $\mathrm{UH}$, mais distantes do Centro histórico, onde é permitido também o uso comercial de prestação de serviço na subcategoria CS1.

O plano engloba também duas Zonas Mistas (ZM), tidas como ZM1 e ZM2. Estas também dispõe-se desta forma em relação a sua proximidade da Zona Central e são destinadas a usos pela ocupação de habitações em pavimentos, onde o primeiro pavimento é destinado ao habitacional e o outro ao comercial. A ZM1 se difere por comportar até 03 pavimentos, para uso comercial ou residencial da subcategoria $\mathrm{PH}$. Já a ZM2 comporta até dois pavimentos, sendo o térreo destinado a comércio da subcategoria CS1 e o outro pavimento a residência para a subcategoria $\mathrm{UH}$.

O Plano também abarca as Zonas de Interesse Paisagístico Ambiental (ZIP), áreas com atributos paisagísticos ou ambientais importantes para o município. Percebe-se sua distribuição na Figura 5, ao longo dos cursos d'água. A Zona da Orla (ZO), é basicamente a zona do cartão postal da cidade, onde se incentiva o lazer, turismo e atividades recreativas. Assim como as Zonas de Equipamentos Estruturantes (ZEE), que reúnem apenas áreas de interesse institucional, sejam públicos ou privados.

As Zonas de Indústria e Abastecimento (ZIA) também são classificadas em dois níveis ZIA1e ZIA2, áreas configuradas no geral como usos para fins de industriais e atividades de produção e transformação. Divergentes entre si quanto às subcategorias de atividades permitidas. A ZIA1 é direcionada a atividades de produção da subcategoria IN1, atividades de alta periculosidade, incomodidade ou elevado potencial poluidor, como Depósito de Gás, Explosivos, indústrias químicas, têxtil e afins. Estas zonas são totalmente incompatíveis com categorias de usos residenciais.

A ZIA2 é destinada ao incentivo de uso para produção e transformação nas atividades atendidas pela subcategoria IN2, que são categorizadas como Industrias de uso incomodo, que em geral causam algum tipo de desconforto, sejam resíduos, odores, ou poluição sonora, como: metalúrgicas, matadouros, etc. Esta categoria também abarca categorias comercias como a categorias CS2 e CS3, como principais exemplos, postos de abastecimento e supermercados respectivamente. A discrepância encontrada no plano é a admissão de uso habitacional da subcategoria $\mathrm{PH}$ nesta zona. O que não se ajusta ao objetivo da indústria na categoria IN2, indústrias incomodas, já que estas deveriam manter-se distantes de habitações residências por gerar resíduos, ruídos e odores, dependendo do tipo de indústria.

A última área descrita no zoneamento são as zonas de expansão da cidade. Como já mencionado, demonstram as tendenciais vetoriais de crescimento da cidade. As rodovias Ernesto Acioly, Sentido Vitória do Xingu, Magalhães Barata, Sentido Serrinha e Br-230-Transamazônica, Sentido Brasil Novo e a Avenida Tancredo Neves, Sentido Aeroporto.

Percebe-se que estas vias indicam os setores destinados a espação, porém ao mesmo tempo as mesmas já estão classificadas como zonas de ocupação. Estas são justamente Zonas Industriais sendo Z1A1, nas Rodovias e Z1A2, na Avenida Tancredo Neves (NORTE ENERGIA, 2011). 


\section{Caracterização da Estrutura Intra-Urbana Atual}

Com o início das obras da Usina Hidrelétricade Belo Monte e a mobilização Migratória, que acarretaram no índice habitacional estimado para o ano de 2014, compreende-se que após 2010, os processos de expansão eram uma necessidade, principalmente para comportar a população residente e os movimentos migratórios influenciados pela obra. Portanto, a adoção da lei de um novo perímetro urbano foi adotada para suplantar a necessidade de novos limites de crescimento.

A demanda populacional pôde ser percebida através da instalação de expressivos empreendimentos imobiliários, que começaram a ser construídos a partir do ano de 2011. No segundo semestre de 2014 chegou-se a cerca de 11 novos empreendimentos imobiliários instalados na cidade, número que mais recentemente, até o primeiro semestre de 2015 permanece inalterado, conforme pode ser observado na Figura 6.

Importante ressaltar que estes estão intercalados com Empreendimentos Particulares, sendo eles loteamentos como Residencial São Francisco, Cidade Nova, Cidade Jardim, Viena e Bonanza; e condomínio fechado, como o Jardim Copacabana; financiamento para baixa-renda, como o Residencial Santa Benedita; e públicos, destinados a realocação de moradores, que são os Reassentamentos Urbanos Coletivos (RUC), implantados como condicionantes à instalação da Usina, são eles: RUC Jatobá, RUC Casa Nova, RUC Água Azul e RUC Laranjeiras.

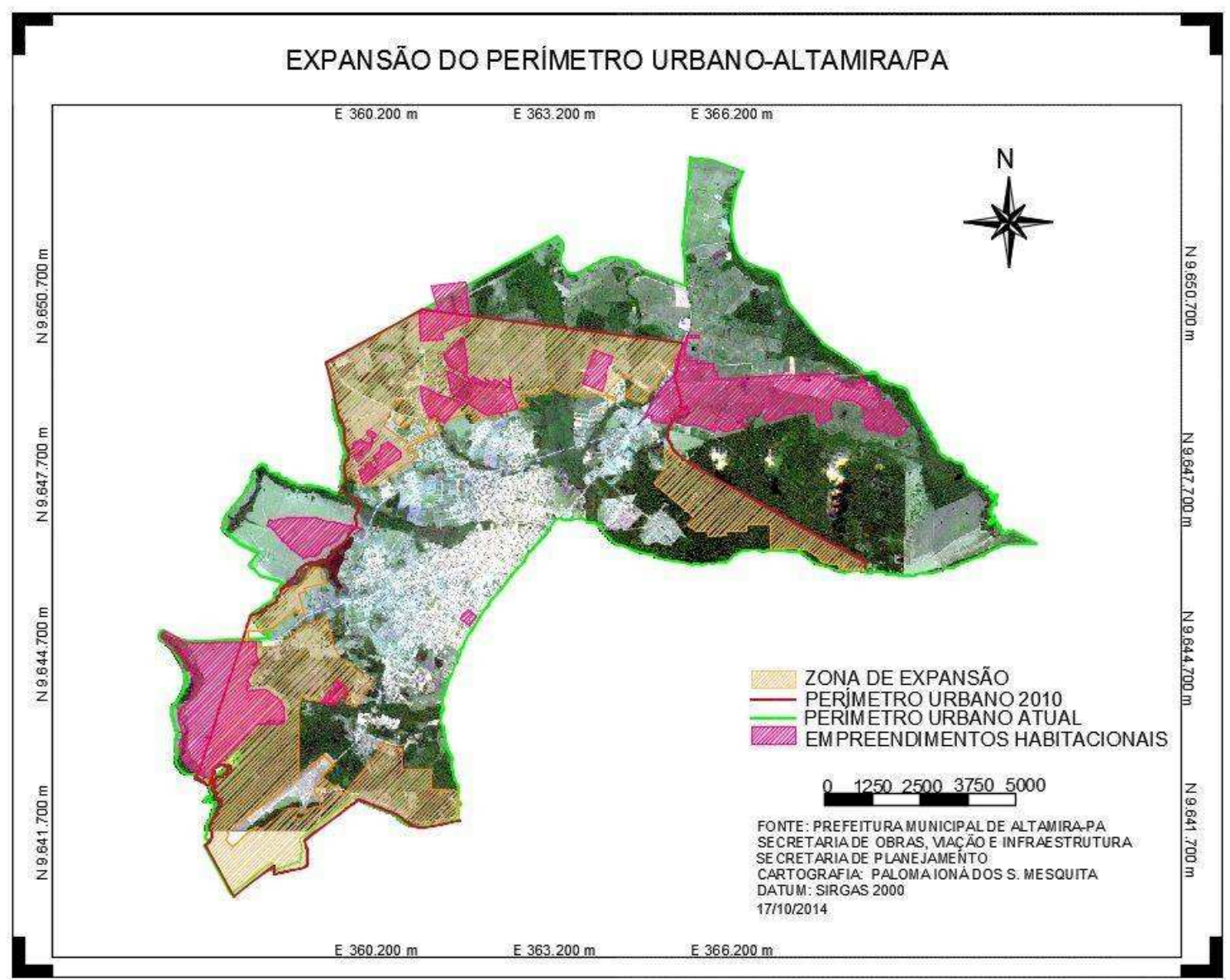

FIGURA 6: Expansão do Perímetro Urbano - Altamira/PA. Fonte: P.M.A./SEOVI/SEPLAN-ATMPA. Elaboração: Elaboração: Mesquita (2014). 
O objetivo da figura 6 é demonstrar visualmente este processo de expansão do perímetro urbano. O destaque da malha desatualizada e da malha atual pretende mostrar os principais vetores de crescimento. A zona de expansão representada no mapa é a zona estabelecida pelo plano Diretor da Cidade no Zoneamento Urbano. Percebe-se como as zonas descritas para expansão pelo Plano Diretor que foi elaborado em 2010, mas aprovado para utilização em 2011, desatualizou-se no mesmo ano em detrimento da grande expansão urbana iniciada e motivadas por obras de Loteamento e Residenciais para atender a demanda local por habitações.

Importante ressaltar que os novos empreendimentos habitacionais se diferenciaram dos antigos estabelecidos na cidade no início da apropriação, pois estes eram incentivados e arcados por empreendedores dentro da própria cidade. Todos os Empreendimentos agora implantados receberam capital de investimento exógeno, o que demonstra a visibilidade do município no cenário nacional, como um polo favorável a investimentos. Principalmente habitacionais ou que supram de alguma forma com as expectativas e necessidades da população residente e migrante (COSTA, 2013).

Torna-se, portanto necessário avaliar o zoneamento urbano atual, quatro anos após este intenso processo migratório e de mudança de centralidades, vistos na Figura 7:

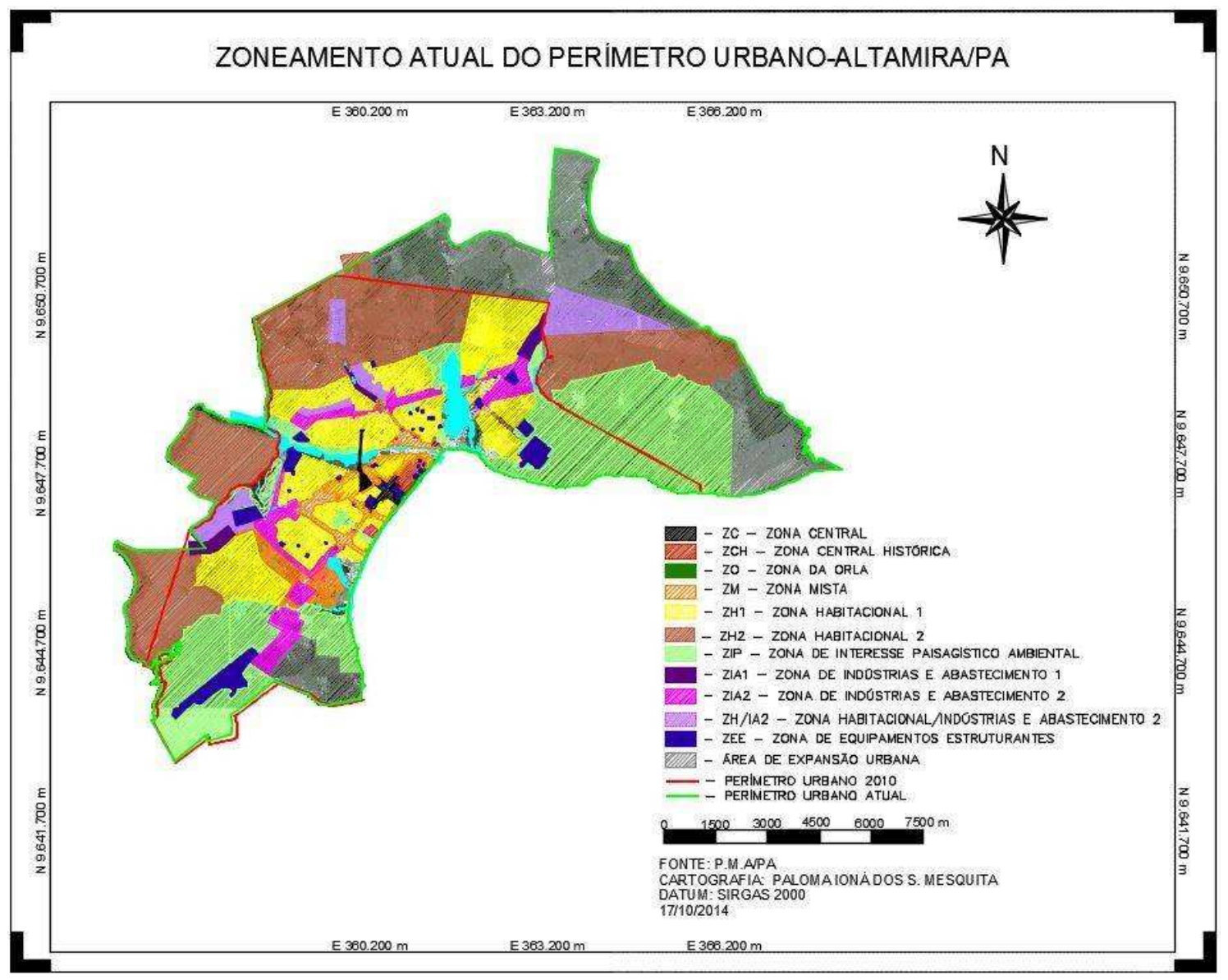

FIGURA 7: Zoneamento Atual do Novo Perímetro Urbano- Altamira/PA. Fonte: P.M.A./SEOVI/SEPLAN-ATM-PA. Elaboração: Mesquita (2014).

Para esta análise foi elaborado um novo mapeamento com enfoque no zoneamento intra-urbano elaborado para o Plano Diretor de 2011, porém levando 
em consideração as novas regiões ocupadas bem como uma análise nas alterações internas nas regiões existentes no período que antecedia o ano de 2011. Projetouse, portanto, um mapa (Figura 7) de atualização do Zoneamento Urbano para o período.

No mapa supracitado, é possível observar como se comportaram as zonas delimitadas no Zoneamento estabelecido no ultimo Plano Diretor, frente à expansão ocorrida. O novo perímetro é empregado juntamente com a permanência do primeiro perímetro, para fins de comparação da expansão tanto em relação às áreas, quanto as zonas estabelecidas.

Os mesmos padrões de classificações continuaram com algumas mudanças visualizadas em campo. Nota-se a criação de uma nova Zona (ZH/IA2). Esta zona mescla o habitacional com as zonas industriais de Nível 2. Este processo foi direcionado pelo próprio zoneamento estabelecido.

Ao permitir que esta categoria de indústria englobasse também habitações residenciais, mesmo sendo industrias classificadas como Industriais de Uso incomodo, a tendência de distribuição fez com que novas moradias fossem criadas pertos destas áreas que também estavam situadas nas rotas de expansão. A equivalência e números residências tanto $\mathrm{UH}$ quanto $\mathrm{PH}$, em consonância com industrias e serviços das subcategorias CS2 e CS3, fez com que a área ficasse mistificada formando uma zona distinta.

As Zonas mistas, antes classificadas como 1 e 2, agora se encontram fundidas devido a perca das características diferenciadoras, que formaram uma fusão entre ambas. As Zonas habitacionais continuam diferenciadas, porém agora as zonas antes classificadas como $\mathrm{ZH} 2$, incorporaram-se as $\mathrm{ZH} 1$, pois o ponto de proximidade com o centro Histórico também se expandiu em relação a nova malha urbana. As ZH2, que eram classificadas como Zonas mais distantes do Centro agora são compreendidas pelos novos empreendimentos habitacionais instalados.

As zonas de interesse paisagístico sofreram alterações durante o processo de reordenação da expansão e avanço populacional. Muitas áreas foram absorvidas pela nova malha de arruamento urbano e Novas Construções. Uma destas intervenções é vista no Projeto da Via de Transposição, do novo sistema viário, interligando a Avenidas Jader Barbalho com a Rodovia Br-230-Transamazônica.

Esta obra é colocada pela Prefeitura Municipal de Altamira, como de grande importância face às necessidades de desafogar o tráfego, principalmente no que diz respeito ao estabelecimento de uma rota principal destinada ao trânsito dos veículos pesados e ônibus, que hoje dominam o trânsito do Município de Altamira, devido ao deslocamento de funcionários para os canteiros de obras. Assim como os tratores e veículos pesados destinados a transporte de materiais para as obras de saneamento básico que vem sendo implantada pelo Consórcio Gel-Gouvêa no município. Porém a mesma esbarra na prerrogativa de zelo ambiental disposta na Lei das Cidades, já comentada neste trabalho.

A Zona de Expansão ou vetor de crescimento que se observa mais recentemente é direcionado a região Nordeste da cidade, sentido as chácaras rurais, em averbação para perímetro urbano. Percebe-se que os demais vetores de crescimento se encontram limitados pelo perímetro atual e no caso do sentido aeroporto, por ser uma área de interesse público. O que nos explicita uma breve restauração do perímetro e aumento da malha urbana. 


\section{CONCLUSÃO}

A cidade de Altamira-PA encontra-se em um processo de evolução demográfico crescente e este acompanhará o processo de obras da Usina Hidroelétrica de Belo Monte que se estenderá pelos próximos anos. É perceptível a grande transformação que a cidade sofreu quando comparada ao ano de 2010, ano do último censo do IBGE e elaboração do Plano diretor de Altamira, com início das obras em 2011 se estendendo com previsão média de 10 anos. A alteração na estrutura intra-urbana e no contingente migrante foi elevada ao ponto de invalidar no mesmo ano de vigência, um Plano Diretor elaborado com base nas características urbanas de 2010 e a malha do perímetro urbano vigente à época.

É notável também a influência de um empreendimento de grande porte na expansão urbana de uma cidade, no qual contribuiu para que houvesse uma reorganização espaço temporal em um breve período, motivando assim, a desatualização acelerada de um grande mecanismo para nortear o planejamento urbano, que foi o Plano Diretor Municipal de Altamira. As áreas compreendidas no zoneamento inicial como áreas de expansão foram ao mesmo tempo limitadas em seus eixos de expansão por zonas totalmente dispares do objetivo de habitação.

A correlação de áreas descompassadas como Indústrias e Habitação, são algumas alterações perceptíveis se analisarmos o que foi definido no Plano Diretor e as características atuais, no qual o novo zoneamento definido neste estudo, ocasionou em uma nova zona, onde a interação entre processos industriais, que envolvem resíduos, incomodo, e principalmente perigo, estão associadas a casas uni e plurifamiliares. Modelos de ocupação com necessidades visivelmente diferentes.

Quanto às alterações sofridas durante o processo, vê-se os avanços sobre as zonas de interesse paisagístico e ambiental, conforme pode ser percebido com a comparação do Mapa de Zoneamento de 2010, com o Mapa de 2014, onde foi elaboradojustamente com objetivo de demonstrar a projeção do primeiro em relação ao período atual.

Percebe-se assim que as zonas de interesses paisagísticos foram eliminadas, tanto pela evolução do arruamento, quanto pela implantação do Projeto de Transposição do Sistema Viário, uma alteração brusca no propósito do plano diretor em relação a evolução de cidades em consonância com a proteção ambiental prevista pelo estatuto das cidades.

Outra alteração percebida diz respeito à divisão das zonas habitacionais: Houve a fusão entre as zonas que antes eram classificadas como zonas de habitação 2, por serem distantes da zona central, com a zona de habitação 1, que eram as mais próximas a esta área. Este fato se deve através de um processo natural, à medida que a cidade avançará em direção aos seus eixos de expansão e contribuindo para a formaçãode novas zonas de habitação 2, como foi o caso dos novos loteamentos e demonstrados no mapa de zoneamento atual.

O processo de expansão e transformação intra-urbano em 4 anos foi notável, como pôde ser avaliado nos mapas e suas análises. Isto nos leva a considerar que em breve surgirá um novo perímetro urbano, tendo em vista a constante expansão urbana. Será necessário, portanto, uma nova organização e planejamento das futuras áreas de expansão, evitando construções desordenadas e degradação de áreas ambientalmente frágeis, que acarretará em outros problemas ambientais e urbanos. 


\section{REFERÊNCIAS}

ALTAMIRA, Prefeitura Municipal/Technum. Processo de Revisão do Plano Diretor do município de Altamira-PA, Lei № 2.178 de 07 de Abril de 2011. Volume I A. 2011.

AMORIM FILHO, O. B. Um modelo de Zoneamento Morfológico funcional do Espaço Intra-Urbano das Cidades Médias de Minas Gerais. In AMORIM FILHO, O.B.; SENA FILHO, N. A morfologia das cidades médias. Goiânia: Ed. Vieira, 2005.

ARAÚJO, A. N; VELOZO, A. D; OLIVEIRA, F. V; BARBOSA, M.A.P; OLIVEIRA, P.B. Região Venda Nova BH: análise do processo de urbanização com utilização do SIG. 2007. 135 f. Monografia (Graduação) - Pontifícia Universidade de Minas Gerais, Programa de Graduação em Geografia com ênfase em Geoprocessamento.

BRASIL, Estatuto da cidade: Lei n. 10.257, de 10 de julho de 2001, que estabelece diretrizes gerais da política urbana. Brasília: Câmara dos Deputados, Coordenação de Publicações, 2001. 35 p. - (Série fontes de referência. Legislação; n. 40).

Zoneamento Territorial. Ministério do Meio Ambiente. Brasília, 2014.

. Lei no 4.297, de 10 de julho de 2002. Regulamenta o art. 9o, inciso II, da Lei no 6.938, de 31 de agosto de 1981, estabelecendo critérios para o Zoneamento Ecológico- Econômico do Brasil - ZEE, e dá outras providências. Diário Oficial da União, Brasília, DF, 11 jul. 2002.

CARVAlHO, C. S. I. \& ROSSBACH, A. O Estatuto da Cidade: Comentado. São Paulo: Ministério das Cidades: Aliança das Cidades, 2010. 120 p.

CARVALHO, P.F. de, \& BRAGA, R. (orgs.) Perspectivas de Gestão Ambiental em Cidades Médias. Rio Claro: LPM-UNESP, 2001. pp. 95 a 109. (ISBN 85-89154-033).

CHENG, J. Modelling spatial \& temporal urban growth. 2003. 203p. Theses (doctoral in geographical sciences). Utrecht University. Utrecht. 2003.

COSTA, É.F.N.;Periferização, dispersão e fragmentação urbana em cidades intermediárias da Amazônia: o caso de Altamira, Pará. 2013. 159 p. Dissertação (Mestrado em Desenvolvimento e Meio Ambiente Urbano) - Programa de Mestrado em Desenvolvimento e Meio Ambiente Urbano, Universidade da Amazônia.

FARINA, F.C. Abordagem sobre as técnicas de geoprocessamento aplicadas ao planejamento e gestão urbana. Cadernos EBAPE.BR. Rio de Janeiro. v.4 n.4, 2006. Disponível em: <www.unilasalle.br>. Acessado em: 07/set/2014.

IBGE, Instituto Brasileiro de Geografia e Estatística. Estimativa da População 2014. Disponível em: <http://cidades.ibge.gov.br/xtras/perfil.php?codmun=150060>. Acessado em: 10out2014.

IBGE, Instituto Brasileiro de Geografia e Estatística. Sinopse do Censo 
Demográfico 2010. Ministério do Planejamento, Orçamento e Gestão. Rio de Janeiro, 2010.

LEITE, M. E. \& BRITO, J. L. S., Sensoriamento Remoto e SIG aplicados ao mapeamento do uso do solo urbano de Montes Claros/MG. Anais XV Simpósio Brasileiro de Sensoriamento Remoto - SBSR, Curitiba, PR, Brasil, 30 de abril a 05 de maio de 2011, INPE p.0933.

FERNANDES, S. C. L.; A Evolução Espacial da População da Microrregião de Altamira, no Estado do Pará. In: XIII INIC / IX EPG - UNIVAP 2009, São José dos Campos. IX Encontro de Pós-Graduação UNIVAP 2009.

MEDINA, L. L. A legislação de uso e ocupação do solo do Recife como instrumento de desenho urbano. Encontros Nacionais da ANPUR. 2013.

MOURA, A. R.; RIBEIRO, J. C. Altamira no contexto geográfico. Belém, PA: Ed. Do Autor, 2009. 119p.

NORTE ENERGIA. Plano de Requalificação Urbana. Projeto Básico Ambiental. 2011. Disponível em:<http://norteenergiasa.com.br/site/2012/05/16/projeto-basicoambiental-da-uhe-belo-monte/>. Acessado em 24jul. de 2014.

NOGUEIRA, C. S. \& RIPPEL, R. Migração Pendular: Estudo de caso da faculdade de Assis Gurgacz-Cascavel (PR). Revista Thêma et Scientia - Vol. 2, $n^{\circ} 2$, jul/dez 2012.

PEREIRA JÚNIOR, A. OLIVEIRA, B. R. S. PEREIRA, E. R. Divergências Entre o Plano Diretor Participativo e a Expansão Urbana Desordenada: o Caso do Município de Marabá In: Enciclopédia Biosfera, Centro Científico Conhecer - Goiânia, v.11 n.21; p. 2459-2466. 2015.

POLIDORO, M. e BARROS, M. V. F. Considerações Sobre a Expansão Urbana dos Municípios Paranaenses Localizados em Trecho da Rodovia BR-369. In: Revista Brasileira de Gestão e Desenvolvimento Regional.v. 8, n. 3, p. 322-341, setdez/2012, Taubaté, SP, Brasil

SANTOS, M. Território e Sociedade. São Paulo: Editora Fundação Perseu Abramo, 2000.

SANTOS, R. F. Planejamento ambiental: teoria e prática. São Paulo: Oficina de Textos, 2004.

TAKEDA, M. M. G. PEREIRA NETO, O. C. BARROS, M. V. F. PEREIRA, G. CARDOZO, F. S. SHIMABUKUR0, Y. E. Caracterização geoambiental da bacia urbana córrego Roseira-Londrina/PR utilizando sistema de informações geográficas (SIG). Revista Eletrônica Geoaraguaia. Barra do Garças-MT. Edição Especial. p. 56 - 76. Setembro. 2013.

VAZ. J. C. Legislação de uso e ocupação do solo. Dicas $\mathrm{n}^{\circ} 77$. Instituto ENCICLOPÉDIA BIOSFERA, Centro Científico Conhecer - Goiânia, v.11 n.22; p.159 2015 
Polis.1996. Disponível em: <http://polis.org.br/publicacoes/dicas/default.asp>. Acessado em: 24/out/2014. 